\title{
Resources Information Management Based on B/S Structure: Design and Implementation
}

\author{
HE Dinghua, a \\ ${ }^{1}$ Department of Computer, Wuhan Polytechnic, Wuhan 430074, China \\ ahedinghuawh@126.com
}

Keywords: B/S Structure; Resources Information Management; Information Technology

\begin{abstract}
With the development of information technology, network technology and communication technology, mankind has entered the information society. Information society of enterprise management concepts, methods brought revolutionary changes in enterprise information management is a big trend in today's world of business development, is one of the effective means of enterprises in the unbeaten status in the competition. Enterprise timely access to information, the information can be fully utilized has increasingly become an important factor to measure a company's competitiveness in the market. This paper introduces the B / s structure information management system applications related technologies, and discusses the enterprise design Resource information management System. This paper studies the use of structural models of corporate information resources management system, it is reasonable to configure enterprise information resources to effectively tap and play information resources, and through the model to help companies improve their decision-making more scientific and efficient, which gives full swing business information and provide a reference.
\end{abstract}

\section{Introduction}

In today's information age and the development background of economic globalization, the rapid spread of information technology, the degree of information technology companies have been significantly improved, enterprise resource management information system has become more and more enterprise information technology development direction and goal, however, enterprise resource information management system faces evolving concept of enterprise information, IT increasingly updates and new management philosophy increasingly complex problems arising. How to build enterprise resource information management systems, and building process should pay attention to what aspects of the problem, a key issue for further improvement of enterprise information [1-2]. Business environment facing businesses, making enterprise resource information management system is constantly changing in the development process. This paper discusses issues related to different levels in this changing environment, enterprise resource management information system construction, and to study the problem of enterprise resource management information system architecture model from both theoretical and practical point of view, its structure and associated mode design.

But the pace of many information management systems in technical research and design, development is still lagging behind in Internet technology, making the lack of efficient management of information resources and take advantage of, but also for the information management staff increased the number of additional burden and workload. Therefore, people calling to better reflect the resource information management features, appearance and better integration of Internet technology developed new information management system.

Articles based on the actual needs of information management starting to study the advantages and disadvantages based on B / S structure of information management systems, analyzes the information management systems and related advanced Internet technologies. Improve the system developer productivity, reduce the number of errors, thus speeding up development and simplify the deployment of applications. Is engaged in providing information about the theoretical knowledge and network storage technology has the characteristics of a new generation of Internet-based B / S 
architecture, information systems development personnel. Make the new information management system has better disaster recovery and backup capabilities, providing an important indicator of the quality of large-scale data services and service quality assurance model based on multi-dimensional object storage system.

\section{Our proposed novel theory}

At present, with the development and popularization of computer technology and network technology, adopts B/S structure to build the software system, to solve the resource reuse of information management methods. B/S structure, namely the Browser/Server structure, the presentation layer USES the general Web Browser; Logic layer is located on the Web server by all kinds of application on the server to implement; And the data service layer is provided by such as SQL Server database Server. Work under this structure, the user interface is implemented via the WWW Browser, few transaction logic in the front-end (Browser), but the main transaction logic on the Server side (Server), forming the so-called three layers structure. So it greatly simplifies the client computer load, reduce the cost of system maintenance and upgrade and workload, reducing the overall cost of users [3-5]. The three layers of B/S architecture model structure diagram as shown in 1.

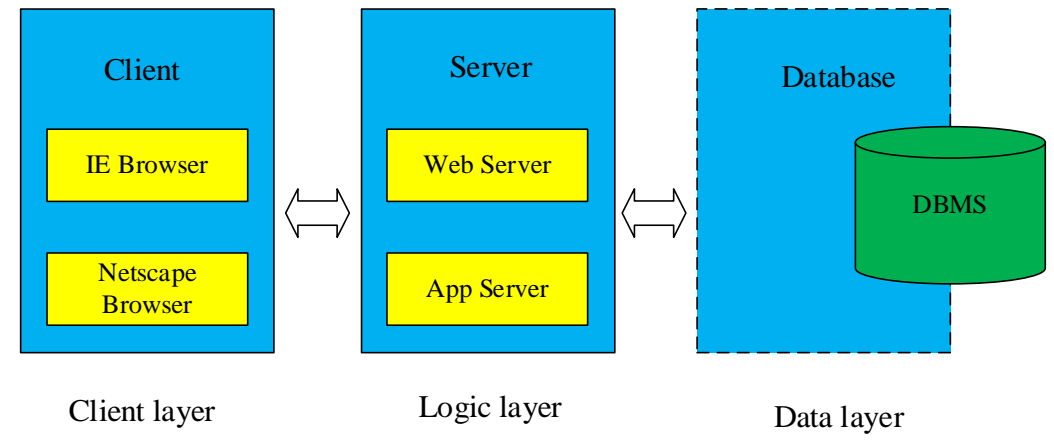

Figure 1. The three layers of $\mathrm{B} / \mathrm{S}$ architecture

Taking into account the actual situation of resource management, we believe that the use of B / $\mathrm{S}$ structure to build resource management information system has the following advantages:

1) System installation and maintenance is simplified. Based on B / S structure of the system is only available on the server, each terminal (such as resource management, subordinate mine) without the need for installation, just through a Web browser can be done given the general operation of the system. Clients in system maintenance and upgrades will save a lot of unnecessary repetitive work that can be completed in a one-time server.

2) Management models become more consistency and concentration. Coal Resource Management Information System Based on B / S structure will define the unified data storage format and data display formats, change the past, the same company all mine all mine data format phenomenon vary radically. Data is centrally stored in the server's database also facilitates users at all levels within the limits allowed range convenient to call these data.

3) Based on system B / S structure can be effective means of networking technology, distributed transaction processing is completed, the results or conclusions with openness. Deliver coal resource information sharing will be smooth, coal companies can better meet the speed of information analysis and information update speed.

4) System based on B / S structure, the main business operations and database operations are concentrated in the server, the client does not require the operator to perform complex analysis and manipulation. Under the premise of the protection of the server operator has a higher operating level, correctness resource information analysis and processing, accuracy, security will be more secure.

\section{Enterprise resource information management system analysis}

Enterprise resource information management system requirements businesses to comprehensive and 
systematic information on enterprise resource management, the specific content shown in figure 2 . However, companies in the construction of their own resources information management system in the process, are often at a loss situation, we continue to see this case: although some companies continue to try to use the latest development technologies, but they still did not escape the failure of information systems The fate; although some companies implemented several systems and information management, but its focus on technical support and troubleshooting aspects of hindsight, therefore, the cost of IT building higher and higher, and the effectiveness of their produce is growing difficult to meet the demands of reality. The failure of the case told us the building of enterprise resource information management systems must be combined with the actual situation of enterprises comprehensive, systematic consideration of various factors [6-7]. Enterprise resource information management system is a complex system. From the development process of enterprise resource information management system, we know that it is in the enterprise has been developed on the basis of certain information technology, combined with enterprise systems through a variety of methods of information technology resources, from a global perspective to deploy , enterprise resource management and application information. Structural model rational enterprise resource information management system was Enterprise Resource Information Management System provides a solution.

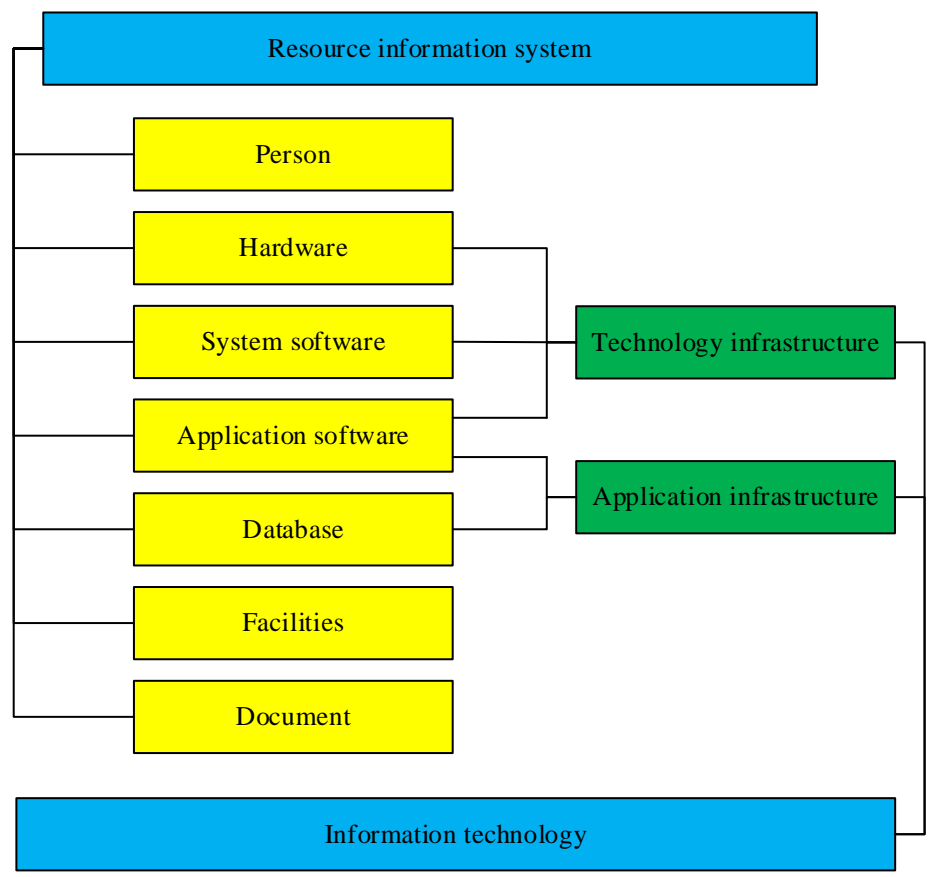

Figure 2. The module of enterprise resource information management system

\section{Three-tier structure model of enterprise resource information management system}

Combined with resource information in the analysis of enterprise applications, from simple information data into information and then information decision applications, structural model of enterprise resource information management system should be divided into the following three:

First, enterprise resource information management system is the topmost decision-making. The ultimate goal of enterprise resource information management system is to achieve corporate decision-making, it will provide an interface enterprise resource information services in corporate decision-making departments, decision makers use the information, and through its decision support system will eventually make all kinds of decisions businesses. Therefore, the uppermost layer in the enterprise resource management information system architecture model is the decision support system.

Second, enterprise resource information management system is the middle layer of management. Information management is integrated enterprise resource management, thus forming a business information service portal, which provides information to support decision-making interface for 
decision support layer, while meeting all other information services companies, management should also be an open The platform can be implemented across the enterprise services to facilitate Internet access through partnership enterprise information application platform, up and down the supply chain, enterprise information application platform, and information application platform and other relevant government agencies. This platform application reflects the characteristics of the different way the common use of property rights, is the enterprise information portal data format standardization trends.

Finally, the bottom of the enterprise resource information management system is the support layer, it is also the core of the enterprise resource information management system. Enterprise resource information management system application layer needs to have a support system, the support system is the basis for enterprise information application module can be successfully applied in the enterprise implementation, enterprise resource information management system to ensure the ultimate success of the premise, it is mainly for business internal resource information management, support layer structure in Chapter 4 will conduct a detailed structural model analysis and design. It should consist of five modules: activities of the enterprise information flow, information systems and IT technology, IT service management, models and methods as well as the management of change. Many enterprise resource information management system in the enterprise failed to achieve its effect, the reason is often at a loss due to the support layer. Enterprise resource information management system as a whole structure model shown in Figure 3:

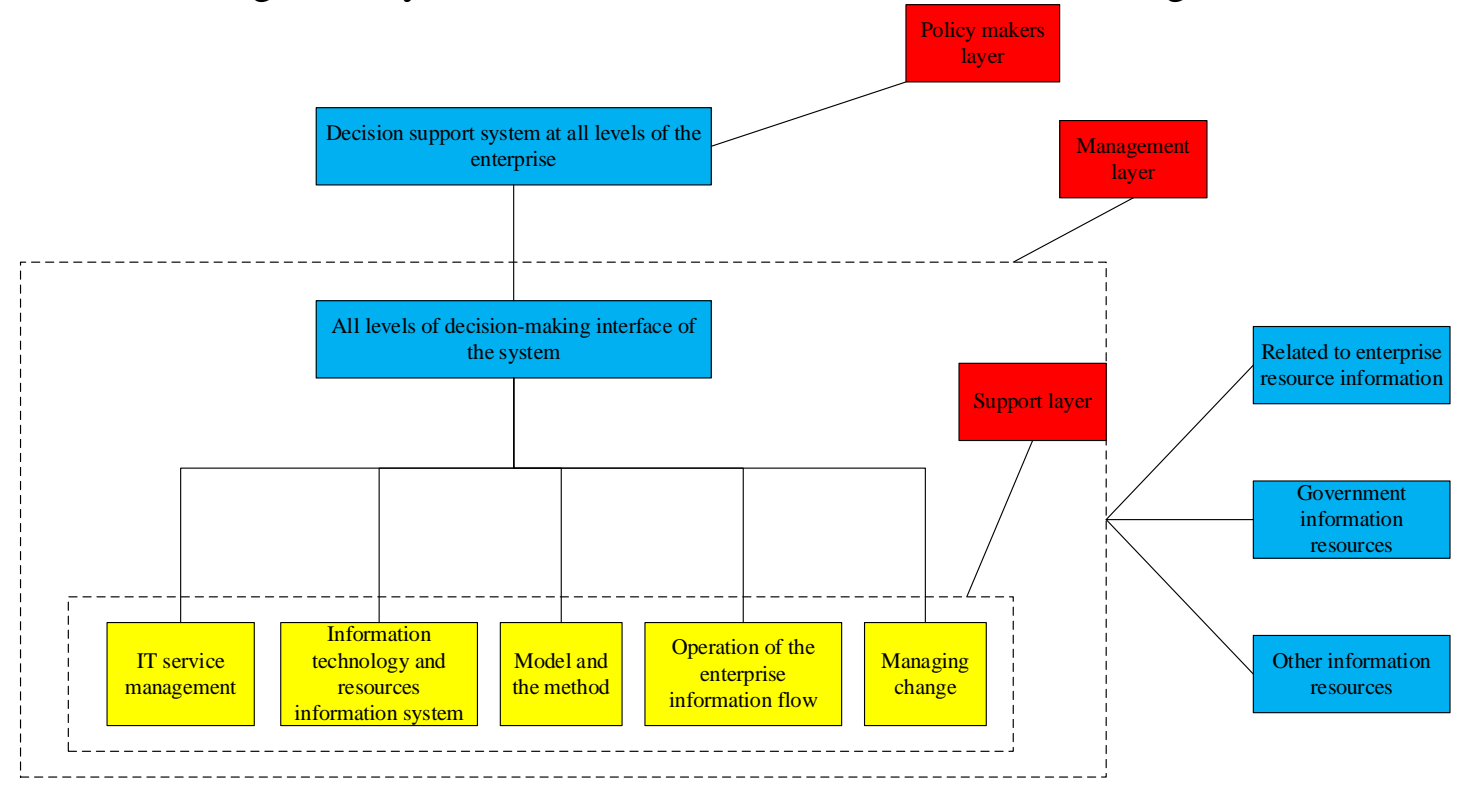

Figure 3. Three-tier structure of enterprise resource information management system

\section{Conclusion}

In today's information age and the development background of economic globalization, the rapid spread of information technology, the degree of information technology companies have been significantly improved, enterprise resource management information system has become more and more enterprise information technology development direction and goal. Prospects enterprise resource information management system will usher a period of rapid development process, while under the influence of information products network effects, enterprise resource information management system will be widely spread. Structure model of enterprise resource information management system largely summed up companies in the information construction of some of the lessons for the ongoing construction of enterprise information, the company offers a counseling program, but also for the development of information technology has been in transition enterprises period provides improved ideas. Of course, the enterprise resource information management system is currently still in the exploration of the theory and practice, this paper presents the structure of 
such a system has yet to be improved and added better, but also need to constantly sum up and discover enterprise information management of resources process problems and solutions.

\section{Acknowledgements}

Scores query based on Android mobile App design and development, Subject of Wuhan Polytechnic, 2014.

\section{References}

[1] Tallis H, Levin P S, Ruckelshaus M, et al. The many faces of ecosystem-based management: making the process work today in real places[J]. Marine Policy, 2010, 34(2): 340-348.

[2] Fugate B S, Stank T P, Mentzer J T. Linking improved knowledge management to operational and organizational performance[J]. Journal of Operations Management, 2009, 27(3): 247-264.

[3] Connelly B L, Certo S T, Ireland R D, et al. Signaling theory: A review and assessment[J]. Journal of Management, 2011, 37(1): 39-67.

[4] Peters C A, Skoog S J, Arant B S, et al. Summary of the AUA guideline on management of primary vesicoureteral reflux in children[J]. The Journal of urology, 2010, 184(3): 1134-1144.

[5] Lester S E, McLeod K L, Tallis H, et al. Science in support of ecosystem-based management for the US West Coast and beyond[J]. Biological Conservation, 2010, 143(3): 576-587.

[6] Kim G, Shin B S, Lee H G. Understanding dynamics between initial trust and usage intentions of mobile banking[J]. Information Systems Journal, 2009, 19(3): 283-311.

[7] Kang S C, Snell S A. Intellectual capital architectures and ambidextrous learning: a framework for human resource management[J]. Journal of Management Studies, 2009, 46(1): 65-92. 